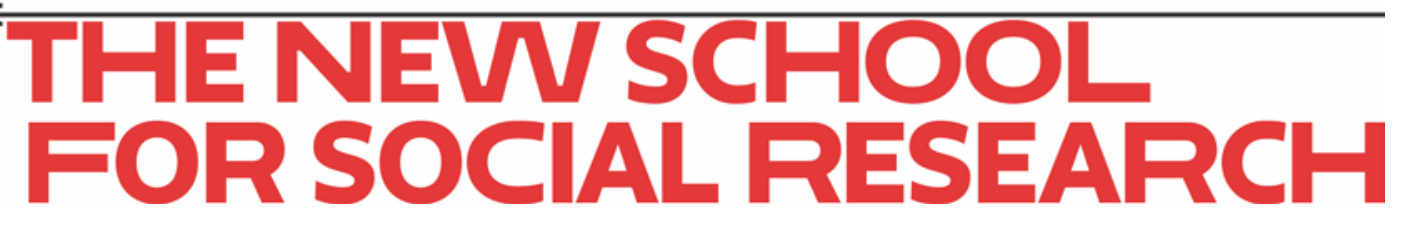

Eduardo F. Bastian and Mark Setterfield

\title{
Nominal exchange rate shocks and inflation in an open economy: towards a structuralist inflation targeting agenda
}

June 2017

Working Paper 20/2017

Department of Economics

The New School for Social Research 


\title{
Nominal exchange rate shocks and inflation in an open economy: towards a structuralist inflation targeting agenda*
}

\author{
Eduardo F. Bastian \\ Institute of Economics, Federal University of Rio de Janeiro (IE-UFRJ) \\ eduardobastian@ie.ufrj.br \\ and \\ Mark Setterfield \\ New School for Social Research \\ mark.setterfield@newschool.edu
}

May 2017

\begin{abstract}
This paper develops a model of inflation in an open economy. The model permits analysis of the susceptibility of open economies to permanent inflationary consequences arising from transitory foreign exchange shocks. Sources of structural vulnerability to such events are identified, and means of addressing these structural vulnerabilities are discussed. Ultimately, the paper arrives at a "structuralist inflation targeting agenda". Based on a proper conception of inflation dynamics, this involves "getting inflation targeting right” rather than either accepting mainstream inflation targeting prescriptions or simply neglecting inflation altogether.
\end{abstract}

JEL Classification Codes: E12, E31, F31, F41

Keywords: Inflation, strato-inflation, nominal exchange rate shocks, conflicting claims, hysteresis, capital controls, industrial policy.

* An earlier version of this paper was presented at the Meetings of the Eastern Economic Association, New York, February 24-26, 2017. The authors would like to thank conference participants and, in particular, 
Gabriel Palazzo, Martin Rapetti, Franklin Serrano, Numa Mazat and Frutuoso Santana for their helpful comments. Any remaining errors are our own. 


\section{Introduction}

Nominal exchange rate shocks affect both the rate of inflation and, by affecting the value of the real wage, the distribution of income. Exchange rate shocks are typically random and temporary, however, so that their effects on inflation and the real wage would also appear to be transitory.

Nevertheless, there seem to be occasions when temporary shocks can have permanent inflationary effects. For instance, Bastian et al. (2016, pp.13-21) show that there were eight episodes of surging inflation in Brazil from 1951 to 1985, seven of which were triggered - or concomitant with - external shocks. ${ }^{1}$ Furthermore, the idea that external shocks are the main trigger of inflationary episodes is central to the German Balance of Payments Theory's interpretation of German hyperinflation in the 1920s, and to the Latin American Structuralist School's analysis of Latin America's chronic inflation of the 1950s and 1960s. These episodes suggest that under certain conditions, even transitory shocks can have permanent effects on inflation outcomes.

In this paper we construct an open economy, conflicting-claims model of inflation in which a nominal exchange rate devaluation can trigger the subsequent propagation of an inflationary spiral. Our approach builds on the open economy inflation model of Blecker (2011) (see also Lavoie, 2104, pp.567-72) and the inflation regime model of Bastian and Setterfield (2015). In the latter, conflicting income claims can give rise to either an equilibrium regime of steady but low inflation, or disequilibrium regimes of

\footnotetext{
${ }^{1}$ According to Bastian et. al. (2016, p.11), “external shocks are identified by a period of successive nominal exchange rate devaluations, a maxi-devaluation and/or a commodity price shock”.
} 
high and rising strato- or hyper-inflation. ${ }^{2}$ Our open-economy extension of this model shows that there are circumstances in which even a temporary nominal exchange devaluation can trigger permanently higher (and rising) inflation, if the initial shock raises the inflation rate above the upper boundary of the equilibrium inflation regime. ${ }^{3}$ This can happens for either of two reasons. The first involves a sufficiently large shock to the rate of inflation. In the case of an open economy, this can happen when there is a sudden and precipitously large devaluation of the nominal exchange rate (or a sequence of smaller devaluations that are cumulatively large). ${ }^{4}$ Second, the inflation rate may already be close to the upper boundary of the equilibrium inflation regime when the shock occurs. Of course, these circumstances are not mutually exclusive: indeed, an economy may be more prone to large nominal exchange shocks precisely when its inflation rate is close to the upper boundary of its equilibrium inflation regime, ${ }^{5}$ or conversely, find that its inflation rate is close to this upper boundary as a result of its being prone to large nominal exchange rate shocks. In short, much depends on the size of the external shock, coupled with the proximity of the inflation rate to the upper boundary

\footnotetext{
${ }^{2}$ Following Jackson and Turner (1972, p. 34), we define strato-inflation as an inflation regime in which the rate of inflation is high and rising due to the increasing intensity with which social groups bargain in order to maintain their real incomes.

${ }^{3}$ According to Bastian and Setterfield (2015), equilibrium inflation regimes materialize and persist only when the actual rate of inflation remains below an upper-bound value that is defined with reference to the bargaining power dynamics of the conflicting claims inflation process. See Bastian and Setterfield (2015, pp.643-646) and section 3.3 below.

${ }^{4}$ Similar effects might be initiated by, for example, commodity price shocks. Ultimately, as Bastian et al (2016) suggest, both variations in relative prices and variations in the nominal exchange rate can be conceived as external shocks that are capable of affecting domestic inflation dynamics in an open economy. In this paper, and for the sake of simplicity, we focus on nominal exchange shocks as the source of external disturbances. For a model wherein the main trigger of inflation is a positive commodity price shock, see Abeles and Panigo (2015).

${ }^{5}$ This observation draws attention to the fact that not all exogenous shocks are created equal: the moments of the distributions of the exogenous shocks that afflict the nominal exchange rates of, for example, the US and Brazil may be (and in all likelihood, are) explicable in terms of structural characteristics of the economies themselves. We exploit this claim in section 4 when we discuss the susceptibility of open economies to permanent inflationary consequences of temporary nominal exchange shocks, and how this might be addressed.
} 
of the equilibrium inflation regime. For reasons that will be made clear, this paper investigates in depth only the first of these problems.

Our analysis reveals structural vulnerabilities of certain types of economies notably, developing countries - to exchange rate shocks and their effects.

By structural vulnerabilities we mean factors such as the composition of final output, the baskets of goods that make up exports and imports, the state of industrial relations, the openness of the economy to international trade and financial flows, and the degree of external indebtedness - features of an economy that are not responsive in the short-term to traditional (monetary and fiscal) macroeconomic policies. For example, countries highly dependent on commodity exports or overly indebted in a foreign currency and with open capital markets are more exposed to sharp exchange rate movements stemming from declining terms of trade or a capital flight, respectively. Moreover, temporary exchange rate shocks are more likely to produce permanent inflationary effects in countries wherein conflicting claims are acute. We therefore ask: can a country’s exposure to the permanent effects of exchange rate shocks be reduced? A first way of achieving this end is to reduce the variance of exchange rate shocks. More precisely, policy-makers can seek to reduce the country’s external vulnerabilities as a way of reducing the magnitude of exchange rate shocks. A second approach involves the adoption of labour market policies to prevent the retaliatory dynamics of a strato-inflation regime so that following a shock, the dynamics of inflation are not explosive. Using the model we develop, we explore different possible strategies for achieving these ends.

The remainder of the paper is organized as follows. Section 2 reviews previous literature linking external shocks to surging inflation, focusing on the German Balance of 
Payments Theory, the Latin American Structuralist School, and contemporary PostKeynesian analyses in the Kaleckian tradition. Section 3 is dedicated to our modified version of Blecker's (2011) model, which we extend to show the possibly permanent inflationary effects of temporary external shocks. Section 4 provides an analysis of how policy-makers can insulate a (developing) country from these events. By way of conclusion, section 5 emphasizes the fact that ultimately, we arrive at a structuralist inflation targeting agenda. Based on a proper conception of the dynamics of inflation, this involves "getting inflation targeting right", rather than either: a) accepting a mainstream approach to inflation targeting and its associated policy prescriptions; or b) simply neglecting inflation altogether. It also involves recognizing that the structural vulnerabilities that make an open economy - and in particular a developing open economy - susceptible to worst-case (strato- and hyper-inflation) outcomes can be overcome. This requires structural policies that, by limiting capital flows, making explicit use of industrial policy, and encouraging social democratic style labour market institutions, are antithetical to the neoliberal "reforms" commonly associated with inflation targeting.

\section{Previous literature}

\section{1 - Pioneering Works}

\section{1.i - German Balance of Payments Theory}

The idea that external shocks (exchange rate devaluations and/ or commodity shocks) are the principle cause of inflation is not new. In fact, it is part of an old tradition 
of cost-push inflation theories. This tradition defies the mainstream view that inflation is due to excess demand.

In the 20th century, the idea that exchange rate devaluations cause inflation featured prominently in the debate over Germany's hyperinflation. ${ }^{6}$ On the one hand, there was the Allied view, which explained Germany’s hyperinflation as a consequence of printing money in response to fiscal disequilibria. Constantino Bresciani-Turroni's classic book (Bresciani-Turroni, 1937) is the best testimony of this monetarist view, which he called the English-Quantitative approach. On the other hand, there was the German Qualitative approach or the German Balance of Payments Theory (GBPT). The GBPT explained Germany's hyperinflation as a consequence of exchange rate devaluations stemming from the country's payments imbalances following World War I, especially the payment of war reparations. This view was defended by Germany's Central Statistical Office, the Reichsbank, and Karl Helfferich, the Secretary of the Treasury (Bastos, 2002: 52-7). ${ }^{7}$

The GBPT ’s arguments were later refined by Joan Robinson. In her 1938 review of Bresciani-Turroni's book, Robinson endorsed the view that exchange rate devaluations were the trigger of Germany's hyperinflation. However, she argued that GBPT wrongly omitted the role of money wages in the ensuing hyperinflation dynamics. Accordingly, she added conflicting claims to GBPT analysis. Hence, Robinson argued that the sharp depreciation of the Mark in 1921 increased the cost of living, leading to demands for

\footnotetext{
${ }^{6}$ For a summary of the most important arguments in the debate, see Bastos (2002).

${ }^{7}$ In his book, Bresciani-Turroni called the German view the German Qualitative approach. According to Bastos (2002), it is better to call it German Balance of Payments Theory because it stresses what German authorities understood as the main causes of the country's inflation, namely exchange rate devaluations due to balance of payments imbalances (Bastos, 2002: 55). According to Câmara \&Vernengo (2001, pp.146-7), Karl Helfferich (1927) was the most notable defender of the GBPT.
} 
higher wages that were granted due to low unemployment and workers poor material conditions. Rising wages increased costs thus counteracting the exchange depreciation effects in the trade balance (Robinson, 1938: 510). As a result, "each rise in wages ... precipitated a further fall in the exchange rate, and each fall in the exchange rate called forth a further rise in wages” (Robinson, 1938: 510).

In sum, Robinson described Germany's hyperinflation as an exchange rate-wageprice spiral. Accordingly, she produced a proto-Post-Keynesian explanation of Germany's hyperinflation (Câmara \& Vernengo, 2001: 148). By combining exchange rate devaluations and distributive conflict, Robinson provided all of the basic elements that would later appear in open economy Post-Keynesian conflicting claims models. ${ }^{8}$

\section{1.ii - The Latin American Structuralist School}

In the 1950s, a new approach - unrelated to the GBPT - advanced the same idea that inflation results form to external shocks stemming from balance of payments imbalances. This approach became known as the Latin American Structuralist School, centred at the Economic Commission for Latin America (ECLA) in Santiago, Chile.

The Latin American Structuralist School (LASS) emerged in 1949 when Raul Prebisch - ECLA`s first general manager - wrote his famous Latin American Manifesto (Estudio Económico de América Latina). Prebisch identified a historical trend of deterioration in Latin America's terms of trade. As Latin American countries were, in general, agricultural and commodity exporters, Prebisch's analysis drew attention to the

\footnotetext{
${ }^{8}$ Charles and Marie (2016) develop a Post-Keynesian model of hyperinflation inspired by Robinson (1938) and Kalecki (1962), wherein they try to "combine Robinson's view of the exchange rate and Kalecki's idea about the importance of expected inflation” (Charles and Marie, 2016: 362). They argue that Robinson and Kalecki "founded the post Keynesian view of hyperinflation" (Charles and Marie, 2016: 362).
} 
need for structural transformation lest the region fall further behind the North. Following Prebisch, numerous ECLA publications emphasized the importance of Latin American industrialization, paving the way for import-substitution policies (Bastos, 2002).

As many Latin American countries experienced high levels of inflation in the wake of their industrialization process, LASS also developed its own ideas regarding inflation during the 1950s and early 1960s. The main contributions were those of Osvaldo Sunkel, Aníbal Pinto, Juan Noyola and Julio Olivera. ${ }^{9}$ These contributions are somewhat heterogeneous, based, as most of them were, on case studies. Nevertheless, it is possible to sum up their fundamental ideas. Following Rodriguez (2009), the core proposition of LASS inflation theory is that inflation is a "real sector phenomenon due to imbalances resulting from rigidities in the external and agricultural sectors”(Rodriguez, 2009: 170). Thus, "inflation is a structural problem because it is the consequence of certain characteristics of the countries 'productive structure” (Rodriguez, 2009: 170). In general, Structuralists tended to divide inflationary pressures into two different categories: a) structural factors; and b) propagation mechanisms. Accordingly, "inflation depends primarily on the structural factors, so that propagation mechanisms are just forces reducing or boosting them” (Rodriguez, 2009: 174; 176).

The structural factors, meanwhile, can be divided into basic pressures and institutional and sociopolitical elements. The latter refer to the way the economy is organized and relate to the degree of concentration in the banking sector and trade union strength. The former refers to the basic structural factors that cause inflation. These consist of the very imbalances that come from the external and agricultural sectors when

9 Sunkel and Pinto were Chileans, whereas Noyola was Mexican and Olivera was Argentinean. 
a country industrializes but is still a commodity exporter. Basic pressures include the slow rate of growth of primary product exports, and the volatility in these exports (in value and volume) and the terms of trade. There is a consequent tendency towards balance of payments disequilibria that result in a recurrent need for exchange rate devaluations. These external disequilibrium and inflationary pressures are reinforced by the characteristics of agricultural supply, which is held to be inelastic and thus incapable of providing the necessary foodstuff in a context of ongoing industrialization (Rodriguez, 2009: $174-7){ }^{10}$

Propagation mechanisms can be of different types. Wage and price adjustments are one possible propagation mechanism of inflationary pressures. Trade unions' bargaining power and firms' degree of monopoly are crucial in determining the importance of this mechanism. This is a typical mechanism in conflicting claims inflation theory. However, LASS mixes this mechanism with other mechanisms associated with demand-pull inflation theory. Accordingly, it identifies a fiscal mechanism, which according to Rodriguez (2009) was the most important propagation mechanism for LASS economists. This mechanism is associated with a tendency towards fiscal deficits due, for example, to the rise of public expenses in order to finance industrialization programs (Rodriguez, 2009: 175). Therefore, LASS defines the tendency to external imbalances as the main cause of inflation. Moreover, it incorporates distributive conflict as a propagation mechanism. However, it mixes these arguments with orthodox interpretations wherein fiscal deficits play an important role in generating inflationary outcomes.

\footnotetext{
${ }^{10}$ LASS blames the concentrated land property structure for the inelasticity of agricultural production (Rodriguez, 2009: 174; 177-8).
} 
A similar tension appears in the late 1960s in the works of Felipe Pazos, a Cuban economist that spent most of his career in multilateral institutions. Although he never worked at ECLA, Pazos' analysis is close to that of the LASS, so that he can be regarded as an heir of this tradition. Moreover, it is worth noting that Pazos realized the similarities between LASS and GBPT when it comes to the link between external shocks and inflation. According to Pazos, the LASS emphasized the role of external sector imbalances due to the sharp fall in the value of primary products exports's, whereas in GBPT the emphasis was on external imbalances due to the payment of war reparations (Pazos, 1969: 11). ${ }^{11}$

Pazos’ (1969) main purpose was to understand Latin America's chronic inflation, which he described as having three characteristics: "1) its long duration; 2) its weak and only occasional acceleration trend; 3) its intermediate intensity comparing to low inflation and hyperinflation cases” (Pazos, 1969; 20-21). In this context of chronic inflation, he identified exchange rate devaluations, stemming from the slow growth of exports and their large fluctuations in volume and value as an important source of inflation. Pazos then introduced a sophisticated analysis of the mechanisms that turn inflation into a chronic process, namely staggered wage contracts and the asynchrony of wage and price adjustments (Pazos, 1969: 108-9).

Pazos' analysis tells the story of a conflicting claims inflation process stemming from a cost shock due to external imbalances. He advanced LASS ideas by providing a deeper analysis of the propagation of inflation. His thinking on staggered wage and price setting and asynchronous adjustments were particularly important in Latin America

\footnotetext{
${ }^{11}$ Pazos (1969) also recognized that in both cases these theories were rivals of conventional (monetarist) demand-pull explanations of inflation (Pazos, 1969: 11).
} 
during the very high inflation and hyperinflation episodes of the 1980s, when a new generation of economists developed these ideas in order to formulate stabilization policies. $^{12}$

Nevertheless, Pazos’ analysis is not completely tied to the concept of conflicting claims inflation. In the manner of earlier LASS contributions, Pazos mixes demand-pull and cost-push explanations of inflation. Besides exchange rate devaluations, he argues that demand-pull and supply pressures, stemming from the slow growth of exports and their large fluctuations in volume and value, cause inflation. On the one hand, public expenditures aimed at reducing unemployment could cause demand pressures. On the other hand, there could be supply pressures due to the insufficiency of imported goods (Pazos, 1969: 109). A cost shock (exchange rate devaluation) was just one possible channel stemming from the external imbalances. In sum, Pazos does not give any primacy to cost-push factors as the main determinants of inflation. He argues that in a chronic inflation context inflation is not due exclusively to demand, supply or cost factors (Pazos, 1969: 107-8).

\section{2 - Contemporary Post-Keynesian Analysis}

The pioneering work of the GBPT, LASS and Pazos provide interesting insights regarding external shocks and inflation. However, there are clear limitations to these analyses. None develops a general and formal theory of inflation, because they were

12 These economists are sometimes known as neo-structuralists. Lustig (1988) uses this term to refer to a group of young Latin American economists analyzing the region's inflation experiences in the late 1970s and early 1980s. Many of them used the term inertial inflation to describe the region's inflation propagation mechanisms (Lustig, 1988: 47-8). The concept of inertial inflation is similar to Pazos' chronic inflation analysis, though some of the neo-structuralists were unaware of Pazos' work. Câmara \& Vernengo (2001: 151-3) also refer to this group as neo-structuralists, but suggest that they were not actual heirs of the LASS because their analysis did not highlight the importance of external imbalances and depreciation. 
trying to address "local” problems (Bastos, 2002). Moreover, the arguments mix demandpull and cost-push explanations of inflation (especially in the case of LASS and Pazos). Although Joan Robinson (1938) provided an embryonic Post-Keynesian interpretation of the German hyperinflation, she also limited herself to a descriptive analysis of this specific event.

A formal Post-Keynesian cost-push inflation theory would only be developed later by Kaleckian authors. There are various idiosyncratic models in this tradition, all capturing the same basic insight - that external shocks can propagate into domestic inflationary problems through conflicting-claims-based wage-price inflationary spirals. Contemporary models in this tradition include Vera (2010) and Marie and Charles (2016). Vera (2010) develops a model wherein the economic adjustments following a balance of payments shock may lead to conflict inflation (Vera, 2010: 612-3). More recently, Charles and Marie (2016) analyze the conditions wherein an economy moves from a high-inflation regime to a hyperinflation regime. In their model, firms' expectations of the nominal exchange rate depend on the level of foreign debt and are a crucial factor contributing to the emergence of hyperinflation. ${ }^{13}$

In this paper, we build on a model due to Blecker (1989; 2011) and Lavoie (2014), which itself follows from Rowthorn’s (1977) original conflicting claims model. We modify certain basic aspects of this model, and subsequently extend it (following Bastian and Setterfield, 2015) to show how even temporary nominal exchange shocks can

\footnotetext{
${ }^{13}$ Charles and Marie (2016) generate multiple equilibria, including an unstable equilibrium wherein both the inflation rate and foreign debt are high. In this unstable equilibrium, "a small positive shock on foreign debt and/or on domestic prices will send the economy into a hyperinflationary process. The liquidity preference of agents and expectations on the exchange rate in a context of increasing uncertainty lead them to get rid of domestic currency, corresponding to the definition of hyperinflation given ... above." (Charles and Marie, 2016: 377).
} 
have permanent inflationary consequences. ${ }^{14}$ This allows us to subsequently identify the structural vulnerabilities that can make an open economy susceptible to these outcomes, and to discuss how these structural vulnerabilities might be addressed by policy makers.

\section{Modelling the inflationary effects of nominal exchange rate depreciations}

As noted by Schröder (2015, p.4), open-economy extensions of Kaleckian macro models follow either a “consumer approach” (Blecker, 1989; 2011) or "producer approach” (Bhaduri and Marglin, 1990, section 3; Taylor, 2004, chpt. 7). ${ }^{15}$ The former involves treating imports as final goods, so that variations in the price of imports affects the real wage directly. The latter treats imports as intermediate goods that enter into domestic production, so that variation in import prices affect the real wage through the medium of domestic pricing decisions. As long as consumer goods are imported for subsequent resale by firms (rather than by the final consumers of the goods themselves), so that all imports are properly treated as intermediate goods, the "producer approach" can be thought of as an encompassing approach to the treatment of imports regardless of the composition of the latter. As such, it is used as the basis for the analysis that follows.

\section{1 - Some simple mark up pricing arithmetic}

How does the incorporation of the external sector modify distributive conflict and how, as a result, should the basic conflicting claims inflation framework be modified in

\footnotetext{
${ }^{14}$ In this respect our model bears comparison to that of Charles and Marie (2016) discussed above although as will become clear, the exact processes that we hold responsible for igniting and subsequently propagating a strato- and possibly hyper-inflation episode are different form theirs. There is no reason to believe that the various processes that we and Charles and Marie (2016) emphasize are mutually exclusive, however.

${ }^{15}$ Blecker (2011) and Lavoie (2014) combine elements of both approaches in the specification of the price and wage growth equations that comprise their conflicting-claims inflation model.
} 
the presence of an external sector? We begin by addressing the first question. Drawing on the "producer approach" outlined above, we write:

$$
P=(1+\tau)\left(W a+e P_{f} b\right)
$$

where $P$ is the price of domestic goods, $W$ is the nominal wage, $e$ is the nominal exchange rate, $P_{f}$ is the price of foreign (imported) goods in foreign currency, $a$ and $b$ are the ratios of labour and imported goods (respectively) to total output, and $\tau$ is the actual mark up that prevails in the determination of prices (bearing in mind that, following Kalecki (1971) and consistent with the spirit of the conflicting claims framework, this will reflect not just firm's preferences but also their bargaining power vis-a-vis workers). Equation [1] modifies a simple mark-up pricing equation by including imported goods in the calculation of the average direct cost to which firms apply the mark up in order to price domestic goods. It follows from [1] that:

$$
\begin{aligned}
& (1+\tau) W a=P-(1+\tau) e P_{f} b \\
& \Rightarrow(1+\tau) \omega a=1-(1+\tau) e_{R} b
\end{aligned}
$$

where $\omega$ is the real wage and $e_{R}$ is the real exchange rate. Finally, on the basis of [2], we can state that either:

$$
\begin{aligned}
& \omega=\frac{1-(1+\tau) e_{R} b}{(1+\tau) a} \\
& \left.\Rightarrow \frac{d \omega}{d e_{R}}\right|_{\tau=\bar{\tau}}=\frac{-b}{a}<0
\end{aligned}
$$

or, alternatively:

$$
\tau=\frac{1-\left(\omega a+e_{R} b\right)}{\omega a+e_{R} b}
$$




$$
\left.\Rightarrow \frac{d \tau}{d e_{R}}\right|_{\omega=\bar{\omega}}=\frac{-b}{\left(\omega a+e_{R} b\right)^{2}}<0
$$

Equations [3] and [5] and their associated derivatives demonstrate the distributive consequences of a change in the real exchange rate (which may, of course, be initiated by a change in the nominal exchange rate, $e$ ) in two extreme cases. In the first (equations [3] and [4]), a real exchange rate depreciation (increase in $e_{R}$ ) decreases the value of the real wage, holding the mark up constant. In the second, a real exchange rate depreciation decreases the size of the mark up, holding the real wage constant. The implication is that the modified mark up equation in [1] introduces a third party (the external sector) into the distributive conflict between workers and firms. This, in turn, suggests that when we come to think in terms of the nominal wage and price dynamics associated with workers' and firms’ behaviour in a conflicting claims framework, either:

i) the level of $e_{R}$ should affect the value of the real wage that workers/firms target to account for the effect that it will have on the real wage/mark up; or

ii) the rate of growth of $e_{R}$ should enter into the determination of nominal wage/price growth, as workers/firms seek to index nominal wages/prices to real exchange rate movements in order to protect the real wage/mark up (in much the same way that inflation expectations enter into the determination of nominal wage/price growth in the closed economy conflicting claims model see Lavoie (1992, pp.392-3)) 
In what follows, we pursue the first of these options in order to construct our basic openeconomy, conflicting claims inflation model.

\section{2 - An extended conflicting claims model}

We begin with:

$$
\begin{gathered}
w=\mu_{1}\left(\omega_{w}-\omega\right) \\
p=\varphi_{2}\left(\omega-\omega_{f}\right)
\end{gathered}
$$

where $w$ is the rate of growth of nominal wages, $\omega_{w}$ and $\omega_{f}$ are workers' and firms' preferred or target values of the real wage, respectively, ${ }^{16}$ and $p$ is the rate of inflation. In this formulation, and for the sake of simplicity, we abstract from both technical change and expectations of future price inflation and/or nominal wage growth, which workers and firms would otherwise need to take into account when formulating the rates of growth of nominal wages and prices in equations [7] and [8]. ${ }^{17}$ Following the discussion in the previous sub-section, we then write:

$$
\omega_{w}=\omega_{w 0}+\mu_{2} e_{R}
$$

\footnotetext{
${ }^{16}$ Firms' target real wage is implicit in their target mark up, $\tau_{f}$, in the mark-up pricing equation $P=\left(1+\tau_{f}\right)\left(W a+e P_{f} b\right)$. It follows from this mark up equation that $\omega_{f}=\frac{1-\left(1+\tau_{f}\right) e_{R} b}{\left(1+\tau_{f}\right) a}$. Note that the actual price level at any point in time will result from the actual mark up consistent with the equilibrium wage share derived earlier and that, as previously noted, reflects the influence of workers' bargaining power.

${ }^{17}$ Failure to do so would involve ignoring influences on the ability of either workers or firms to realize the target shares of income implicit in their target real wages. Consider, for example, the case where $\omega=\omega_{w}$ in [7]. The result that $w=0$ does not make sense if workers anticipate increase in prices (which, ceteris paribus, will erode the value of the real wage and thereby negate the desired result $\omega=\omega_{w}$ ) or if there is labour-augmenting technical change (which requires an increase in the target real wage and hence $w>0$ in order to preserve the currently prevailing functional distribution of income) - unless, for some reason, workers do not have either the incentive or the bargaining power to take these factors into account when formulating the value of $w$.
} 


$$
\omega_{f}=\omega_{f 0}-\varphi_{2} e_{R}
$$

Equations [9] and [10] state that the target real wages of workers and firms depend on an exogenous component ( $\omega_{w 0}$ and $\omega_{f 0}$ respectively), and the value of $e_{R}$. The target real wage of workers is increasing in $e_{R}$, in keeping with the sign of the derivative in [4], while that of firms is decreasing in $e_{R}$, in keeping with the sign of the derivative in [5]. In both cases, workers and firms can be thought of as seeking to protect their preferred claims on total real income from the encroachment of the external sector.

Finally, substitution of equations [9] and [10] into [7] and [8] (respectively) yields our open-economy conflicting claims inflation model:

$$
\begin{aligned}
& w=\mu_{1}\left(\left[\omega_{w 0}+\mu_{2} e_{R}\right]-\omega\right) \\
& p=\varphi_{1}\left(\omega-\left[\omega_{f 0}-\varphi_{2} e_{R}\right]\right)
\end{aligned}
$$

Equations [11] and [12] are a modified version of the model presented by Blecker (2011) and Lavoie (2014, pp. 567-72) (hereafter, the BL model). The chief modification involves consistent appeal to strategy (i) outlined in the previous sub-section - that is, the principle that the level of $e_{R}$ affects the target value of the real wage that workers/firms pursue. This modification appears modest but is, in fact important. In the BL model, firms adjust their real wage target in response to the level of $e_{R}$ (as in strategy (i)), while workers' behaviour is closer to strategy (ii) - but involves incorporating the level rather than the rate of growth of $e_{R}$ into the determination of nominal wage growth (in addition to the discrepancy between the target and actual real wage). In our view, the asymmetry in behaviour this involves is unwarranted: why do workers and firms respond to the effects 
of the real exchange rate on their real income shares in such qualitatively different ways? More importantly, the precise description of workers' behaviour in the BL model appears to be conceptually flawed. Hence even with their target real wage realized, workers in the BL model will continue to demand nominal wage increases in response to any $e_{R}>0$. But since a constant $e_{R}$ will not change the value of the real wage ceteris paribus, and since the real wage is (by assumption) already at its target value, why will workers seek to further increase the nominal wage? This critique suggests that the formulation of worker behaviour in the BL model lacks an appropriate behavioural foundation, and that its reformulation in equation [9] solves this problem.

Using equations [11] and [12], we can now find the equilibrium real wage (referred to as the distribution curve, DC, in the BL model) by imposing the constant real wage equilibrium condition: ${ }^{18}$

$$
w=p
$$

This yields:

$$
\omega^{*}=\frac{\mu_{1} \omega_{w 0}+\phi_{1} \omega_{f 0}+\left(\mu_{1} \mu_{2}-\phi_{1} \phi_{2}\right) e_{R}}{\mu_{1}+\phi_{1}}
$$

Substituting this solution into [12] then yields the accompanying equilibrium rate of inflation: ${ }^{19}$

$$
p^{*}=\frac{\mu_{1} \phi_{1}\left[\left(\omega_{w 0}-\omega_{f 0}\right)+\left(\mu_{2}+\phi_{2}\right) e_{R}\right]}{\mu_{1}+\phi_{1}}
$$

\footnotetext{
${ }^{18}$ In the BL model, the DC curve shows the indirect relationship between the (constant equilibrium) wage share of income and the real exchange rate, such that as the real exchange rate increases (i.e., the value of domestic currency depreciates in real terms), the equilibrium wage share declines.

19 The equilibrium solution for the rate of inflation is not derived in the BL model, but the value of the equilibrium rate of inflation can, in principle, be recovered from the equilibrium solutions for other variables in the system.
} 
Now note that both of the equilibrium solutions derived above are predicated on a constant real exchange rate which, taking the foreign rate of inflation as given, presupposes that the nominal exchange rate behaves in an accommodating fashion (as a residual consequence of the system's equilibrium dynamics). The precise behaviour required of the nominal exchange rate can be made explicit as follows. First, note that by definition:

$$
\begin{aligned}
& e_{R}=\frac{e P_{f}}{P} \\
& \Rightarrow \dot{e}_{R}=e_{R}\left(\hat{e}+p_{f}-p\right)
\end{aligned}
$$

so that with $p_{f}=\bar{p}_{f}$ and $p=p^{*}$ (as in [14]), $\dot{e}_{R}=0$ (i.e., constancy of the real exchange rate, as assumed in [13] and [14]) requires that: ${ }^{20}$

$$
\begin{aligned}
& \hat{e}^{*}=-\bar{p}_{f}+\frac{\mu_{1} \phi_{1}\left[\left(\omega_{w 0}-\omega_{f 0}\right)+\left(\mu_{2}+\phi_{2}\right) e_{R}\right]}{\mu_{1}+\phi_{1}} \\
& \Rightarrow \hat{e}^{*}=\frac{\mu_{1} \phi_{1}\left(\omega_{w 0}-\omega_{f 0}\right)-\left(\mu_{1}+\phi_{1}\right) \bar{p}_{f}}{\mu_{1}+\phi_{1}}+\frac{\mu_{1} \phi_{1}\left(\mu_{2}+\phi_{2}\right)}{\mu_{1}+\phi_{1}} e_{R}
\end{aligned}
$$

To summarize, equations [13]— [15] describe an extended conflicting claims model in which the "conventional” conflicting claims equilibrium outcomes $\left(\omega^{*}\right.$ and $p^{*}$ in equations [13] and [14]) depend on a constant (but indeterminate) value of the real exchange rate. In turn, the constancy of the real exchange rate required to derive the equilibrium values of $\omega^{*}$ and $p^{*}$ imposes certain dynamics on the nominal exchange rate, which plays the role of a residual adjusting variable under the implicit assumption of a floating nominal exchange rate regime. ${ }^{21}$ These dynamics are described by the

\footnotetext{
${ }^{20}$ We assume here that $e_{R}>0$, so that $\dot{e}_{R}=0$ requires $\dot{e}=p-p_{f}$.

${ }^{21}$ As will become clear below, the floating nominal exchange rate regime may be "managed” or "dirty".
} 
equilibrium rate of appreciation or depreciation of the nominal exchange rate in equation [15]. The behaviour of the system as a whole is captured in Figure 1. The top-right quadrant of Figure 1 depicts the interaction of the wage and price setting behavior as described in equations [11] and [12]. The top-left quadrant, meanwhile, illustrates the direct relationship between the equilibrium rate of inflation derived from [11] and [1]2, and the value of the real exchange rate assumed in this derivation (as in equation [14]). Finally, the bottom-left quadrant describes the implied behavior of the nominal exchange rate (as in [15]). Note that it follows from equation [15] that if it is possible for the policy authorities to manage the real exchange rate towards an appropriate target value and/or influence the bargaining power of workers and firms (through an incomes policy, for example), then it is possible to engineer a constant nominal exchange rate consistent with the equilibrium outcomes of the extended conflicting claims framework. In terms of Figure 1, this would involve manipulating policy instruments designed to shift and/or rotate the $\hat{e}$ schedule so as to reconcile the equilibrium of the model with the $\hat{e}=0$ dashed line in the bottom-left quadrant.

\section{[FIGURE 1 GOES HERE]}

As noted above, the real exchange rate in our model is given and can, therefore, take any arbitrary value. This appears to contrast with the treatment of the real exchange rate in the BL model, in which an explicit target value of the real exchange rate, formulated by the policy authorities, is postulated. Closer inspection reveals, however, that the difference between the two models is more apparent than real. This is because the equilibrium of the BL model is not a "fully adjusted position". Hence the formulation of the foreign exchange (or FE) curve in this model differs from the FE curve that would 
arise if the value of the real exchange rate were equal to its target value (see Lavoie, 2014, p.569, equation (8.27)). ${ }^{22}$ Ultimately, then, the equilibrium value of the real exchange rate in the $\mathrm{BL}$ model is indeterminate, resulting in a non-zero equilibrium rate of growth of the nominal exchange rate (see Lavoie, 2014, p.569, equation (8.26 )). ${ }^{23}$

\section{3 - Nominal exchange rate depreciations}

The model developed above treats the nominal exchange rate as a residual adjusting variable (as described in [15]) that accommodates an equilibrium configuration comprising a determinate real wage and rate of inflation and a given real exchange rate. But in addition to the systematic adjustment described in equation [15], the appreciation or depreciation of the nominal exchange rate can be thought of as being subject to random shocks emanating from outside the conflicting-claims system described so far.

Intuitively, it would seem that such shocks - being once over and temporary should have little lasting effect on the outcomes described in equation [13] — [15] and summarized in Figure 1. The intuition for this result is illustrated in Figure 2. Beginning with the equilibrium $\hat{e}_{1}^{*}$, consider a random shock to nominal exchange rate dynamics of size $\varepsilon>0$ (where $\varepsilon \sim\left(0, \sigma_{\varepsilon}^{2}\right)$ ), such that $\hat{e}_{2}=\hat{e}_{1}^{*}+\varepsilon$. As is clear from Figure 2 , this increased rate of depreciation raises the value of the real exchange rate (the real exchange rate depreciates). As a consequence, the domestic wage and price inflation curves shift

\footnotetext{
${ }^{22}$ In the BL model, the FE curve describes the direct relationship between the (constant equilibrium) real exchange rate and the wage share of income, such that as the wage share rises, the value of the equilibrium exchange rate rises (i.e., the domestic currency depreciates in real terms). Were equality of the equilibrium and target real exchange rates established in the BL, then the target rate would disappear from the solution for the equilibrium rate. The shift in the FE schedule in the comparative static exercise discussed by Lavoie (2014, pp.570-71) could not then occur.

${ }^{23}$ By virtue of these properties, both our own model and the BL model are perhaps best regarded as short run models.
} 
upwards (see equations [11] and [12]), as depicted in the top right quadrant of Figure 2.

This establishes a new, higher equilibrium rate of inflation $p_{2}{ }^{*}$ consistent with the depreciated real exchange rate $e_{R 2}{ }^{*},{ }^{24}$ and a new lower value of the equilibrium real wage, $\omega_{1}{ }^{*}$. The latter result is consistent with the assumption that $\mu_{1} \mu_{2}-\varphi_{1} \varphi_{2}<0$ in equation [13]. In other words, we are assuming that firms are willing and/or able to respond more aggressively to discrepancies between the actual and target real wage and/or variations in the real exchange rate when determining the rate of increase of prices in equation [12] than are workers as they seek to affect the rate of increase of nominal wages in equation $[11] .{ }^{25}$ Recall, however, that the shock responsible for the new configuration depicted in Figure 2 is (by hypothesis) transitory. In the long run, with $\varepsilon=0$, we will once again observe $\hat{e}=\hat{e}_{1}^{*}$, and so the system will revert to the initial equilibrium configuration $\hat{e}_{1}^{*}, p_{1}^{*}, \omega^{*}$ simply because of the disappearance of the shock. The shock - and hence the departure from the original equilibrium position - may, of course, be persistent if, for example, $\varepsilon=\alpha \varepsilon_{-1}+\eta$ where $\alpha<1$ and $\eta \sim\left(0, \sigma_{\eta}^{2}\right)$. But persistence constitutes only a relatively enduring effect on inflation. A transitory shock to nominal exchange rate dynamics will seemingly, therefore, have only a transitory effect on inflation dynamics.

\section{[FIGURE 2 GOES HERE]}

Further consideration reveals, however, that events may be less straightforward. According to Bastian and Setterfield (2015), the parameters $\mu_{1}$ and $\varphi_{1}$ in equations [11]

\footnotetext{
${ }^{24}$ Recall that the $p^{*}$ schedule in the top left quadrant of Figure 2 relates the equilibrium rate of inflation, derived from the conflicting-claims process depicted in the top right quadrant, to the value of the real exchange rate. See equation [14].

${ }^{25}$ Although seemingly arbitrary for the purposes of the results depicted in Figure 2, it will become clear in what follows that this particular configuration of relative bargaining power as between workers and firms may be of considerable importance for the effects of nominal exchange rate shocks on domestic inflation dynamics.
} 
and [12] represent the actual extent to which workers and firms bargain in the pursuit of their real wage targets, as distinct from their potential bargaining power $\mu_{1 \max }$ and $\varphi_{1 \max }$, where $\mu_{1}<\mu_{1 \max }$ and $\varphi_{1}<\varphi_{1 \max }$ because of satisficing behavior. Hence if the current wage share is "close enough" to $\omega_{w}\left(\omega_{f}\right)$, there is no incentive to exert additional bargaining effort (which is costly) since with $\omega$ "close enough" to $\omega_{w}\left(\omega_{f}\right)$ there is nothing to gain. ${ }^{26}$ But the satisficing behaviour so-described has its limits. According to Bastian and Setterfield (2015), we can write:

$$
\begin{aligned}
& \Delta \mu_{1}=\mu_{1}\left(\omega_{w}-\omega^{*}\right) \quad \text { if } \quad \omega_{w}-\omega^{*}>c \\
& =0 \quad \text { if } \quad \omega_{w}-\omega^{*} \leq c \\
& \Delta \varphi_{1}=\varphi_{1} \Delta \mu_{1}
\end{aligned}
$$

where $c$ is a conventional constant. Equation [16] formalizes both workers' satisficing behavior in the wage bargaining process $\left(\Delta \mu_{1}=0\right.$ if $\left.\omega_{w}-\omega^{*} \leq c\right)$ and the limits to this behaviour $\left(\Delta \mu_{1}>0-\right.$ assuming that $\mu<\mu_{\max }$ initially - if $\left.\omega_{w}-\omega^{*}>c\right)$. Equation [17] describes a process of retaliation by firms (assuming $\varphi_{1}<\varphi_{1 \max }$ initially). Together, equations [16] and [17] describe a leader-follower dynamic in bargaining intensity in the event that $\omega_{w}-\omega^{*}>c$.

The significance of all this is revealed if, once again following Bastian and Setterfield (2015), we treat the equilibrium inflation regime depicted in Figures 1 and 2 as a special case situation in which the rate of inflation rate is sufficiently low - i.e., at or below a certain upper boundary $p_{s}$, at which, in conjunction with the current bargaining

\footnotetext{
${ }^{26}$ In reality, it may not be the distance of the equilibrium wage share from its target value that triggers an increase in bargaining effort, but instead the size of the change in the wage share from one period to the next that has this effect. For the sake of simplicity we abstract from this possibility here and in what follows.
} 
posture of labor $\left(\mu_{1}\right), \omega_{w}-\omega=c \Rightarrow \omega=\omega_{w}-c .{ }^{27}$ For $p^{*}<p_{s}$, then, $\Delta \mu=\Delta \varphi=0$ in [16] and [17], with the result that $p^{*}$ is indefinitely self-sustaining (ceteris paribus) as in Figures 1 and 2. A strato-inflation regime is then a situation in which inflation surpasses $p_{s}$, so that $\omega^{*}<\omega_{w}-c \Rightarrow \omega_{w}-\omega^{*}>c$ and conflicting claims become acute as we observe $\Delta \mu, \Delta \varphi>0$ in [16] and [17].

What is the significance of all this for the inflationary consequences of nominal exchange rate shocks? Consider again the equilibrium configuration reached in Figure 2. Assume that $p_{1}^{*}=p_{s} \Rightarrow \omega_{1}^{*}=\omega_{w}-c$. It follows that $p_{2}^{*}>p_{s}$ and that $\omega_{2}^{*}<\omega_{w}-c$. In the immediate aftermath of the nominal exchange rate shock $\varepsilon>0$, we will therefore witness the simultaneous unfolding of two dynamic processes - the consequences of which are depicted in Figure 3. First, because of the transitory nature of the shock, we will observe $\varepsilon=0$. Ceteris paribus, this will restore the real exchange rate to $e_{R 1}{ }^{*}$, shifting the $w$ and $p$ schedules back to $w_{1}$ and $p_{1}$ in the top right quadrant of Figure 3 , and restoring the rate of inflation to $p_{1}{ }^{*}$. These developments are all consistent with our earlier interpretation of the inflationary consequences of $\varepsilon \neq 0$ being transitory.

\section{[FIGURE 3 GOES HERE]}

Second, the fact that $p_{2}^{*}>p_{s}$ and $\omega_{2}^{*}<\omega_{w}-c$ will activate the dynamics in equations [16] and [17]. As a result of equation [16], we will observe $\Delta \mu_{1}>0$. This is captured in Figure 3 by a steepening of the $w$ schedule to $w_{3}$. Next, as a result of equation [17], firms will retaliate to the change in workers' bargaining posture ( $\left.\Delta \varphi_{1}>0\right)$. This is

\footnotetext{
${ }^{27}$ As Bastian and Setterfield (2015) explain, the bargaining power of labor is privileged in this definition of $p_{s}$ because of the specific role of workers in the leader-follower dynamic in equations [16] and [17].
} 
captured in Figure 3 by the steepening of the $p$ schedule to $p_{3}$. In Figure 3, it is assumed that together, these developments exactly offset the effects of $\varepsilon=0$ described above, so that $p_{2}^{*}>p_{s}$ and $\omega_{2}^{*}<\omega_{w}-c$ are once again restored as the equilibrium values of the rate of inflation and real wage in the top right quadrant.

Since both $\mu_{1}$ and $\varphi_{1}$ have increased, both the slope and the intercept of the $p^{*}$ schedule will increase, as depicted in the top left quadrant of Figure $3 .{ }^{28}$ Consistent with developments in the top right quadrant of this Figure - in which the $w_{3}$ and $p_{3}$ schedules have been drawn consistent with $\omega_{w}$ and $\omega_{f}$, and hence the value of the real exchange rate, $e_{R}$, taken as given, the shift in the $p^{*}$ schedule in Figure 3 is depicted as reconciling the equilibrium rate of inflation $p_{2}{ }^{*}$ with an unchanging value of $e_{R}=e_{R 1}{ }^{*}$. At the same time, both the slope and the intercept of the $\hat{e}$ schedule will increase in response to the rise in $\mu_{1}$ and $\varphi_{1}$, as depicted in the lower left quadrant of Figure $3 .{ }^{29}$ Consistent with our treatment of the nominal exchange rate as a residual adjusting variable, the consequence of this development is an increase in the rate of depreciation of the nominal exchange rate to $\hat{e}_{3}^{*}$.

This sequence of adjustments is not, of course, the end of the story, since it marks only the onset of what was defined previously as a strato-inflation regime. Hence the outcomes $\omega_{2}{ }^{*}$ and $p_{2}{ }^{*}$ constitute only a "provisional equilibrium” (Chick and Caserta, 1997) - a temporary configuration that awaits subsequent reconfiguration as a result of dynamics that are endogenous to the system. These endogenous dynamics result from the restoration of $\omega^{*}$ to $\omega_{1}^{*}<\omega_{w}-c$ in Figure 3, which will result in further adjustment of the

\footnotetext{
${ }^{28}$ See Appendix A for formal demonstration of these results.

${ }^{29}$ Again, see Appendix A for formal demonstration of this result.
} 
bargaining posture of workers in [16] and, as a result, further retaliation by firms in [17]. These subsequent developments will repeat indefinitely - as a result of which the rate of inflation, if unchecked by policymakers, will increase without limit - as long as $\omega_{i}^{*}<\omega_{w}-c \forall i>1$

The result depicted in Figure 3 is hysteresis-like, suggesting that a transitory nominal exchange rate shock can have permanent effects on the rate of inflation. ${ }^{30}$ This result arises because of a discontinuity in the inflation dynamics introduced by equation [16], coupled with the assumption (in Figure 3) that the initial exchange rate shock causes the rate of inflation to cross a threshold value $\left(p_{s}\right)$ that transforms an equilibrium inflation regime into a strato-inflation regime. The practical lesson for open economies with labour market institutions that permit real-wage resistance is that exposure to even transitory nominal exchange rate shocks can have lasting and serious consequences for domestic inflation. This inevitably raises the question as to how, if at all, policy makers can respond to this situation - a question that we address in the following section.

The result derived above also bears comparison to that of Ribeiro et al (2016), who show that a real exchange rate devaluation can have adverse effects on the real (i.e., growth) dynamics of an economy. Since the temporary nominal exchange rate shock discussed above involves, as its counterpart, a temporary increase in the value of the real exchange rate, we can say that real exchange rate devaluations can also have adverse effects on the nominal (i.e., inflation) dynamics of an economy. This result is clearly a counterpart to that of Ribeiro et al (2016) which, to borrow from the language of their

\footnotetext{
${ }^{30}$ We refer to the result above as hysteresis-like by virtue of its having one of the salient properties of hysteresis - namely, the propensity of a temporary cause to have a permanent effect. It does not, however, arise from a process of "strong” or "true” hysteresis. See Setterfield (2009) for further discussion.
} 
paper, adds to the "unpleasant currency devaluation arithmetic" associated with foreign exchange movements.

\section{Policy implications: strategies for reducing exposure to the lasting inflationary effects of external shocks}

\section{1 - Introduction}

The model developed in the previous section allows us to identify three sources of structural vulnerability to the outcomes summarized in Figure 3 (permanent inflationary consequences arising from transitory foreign exchange shocks). These are:

- the volatility of the nominal exchange rate, as captured by the size of $\sigma_{\varepsilon}^{2}$;

- the distance of the initial equilibrium rate of inflation from the strato-inflation threshold, as captured by the size of $p^{*}-p_{s}$; and

- the initial size and rate of adjustment of the parameter $\mu$ (which affects the extent to which an increase in inflation initiated by a nominal exchange shock subsequently propagates as a strato-inflation).

Note that first two vulnerabilities relate to the ex ante susceptibility of the economy to crossing the strato-inflation threshold, whereas the third concerns the ex post susceptibility of the economy to propagating a strato-inflation once the threshold has been crossed. There are, then, qualitative differences between the structural vulnerabilities identified above. At the same time, these vulnerabilities are not mutually exclusive. On contrary, we conjecture that an economy suffering from one vulnerability more than likely suffers from some combination of the three. This is suggestive of major structural discontinuities among open, resource based economies such as (for example) 
Canada, in which none of the structural vulnerabilities appear to be present, and certain Latin American economies that seem to suffer from some or all of the vulnerabilities identified.

In what follows, we focus our discussion on the first and third of the structural vulnerabilities identified above. This is because both the sources of and the policies required to address these vulnerabilities appear to us to be more obvious. Per the analysis in section 3.3, the distance of the initial equilibrium rate of inflation from the stratoinflation threshold $\left(p^{*}-p_{s}\right)$ is linked to the size of $c$ and hence structural features of the labour market - specifically, the tolerance of workers for departures from the target real wage level. This, in turn, is a function of workers' satisficing behavior. The value of $p^{*}-p_{s}$ appears, therefore, to have complex socio-economic origins, and we leave investigation of this structural vulnerability (and the policies required to address it) to future research.

\section{2 - Reducing of the variance of external shocks}

Developing countries are usually exposed to two types of external shocks that cause depreciation. First, there are financial shocks, namely massive capital outflows. As Chang and Grabel (2005: 112) suggest, “sudden, large capital outflows (termed 'capital flight') can place pressure on the domestic currency to depreciate ... capital flight often induces a vicious cycle of additional flight and currency depreciation, debt-service difficulties and reductions in stock (or other asset) values”.

Second, there are terms of trade shocks. For instance, as many developing countries are mainly exporters of primary goods, a fall in commodity prices will strongly 
affect exports. A common result will then be current account deficits and exchange rate depreciation.

This section discusses the main features of each of these shocks and suggests strategies to reduce developing countries' exposure to them. ${ }^{31}$

\section{2.i - Financial Shocks}

From the 1970s on, there was a broad liberalization of capital markets worldwide. As a result, exchange rate movements became increasingly influenced by capital flows. This is a problematic issue because capital flows - especially short-term capital - are volatile, meaning that changes in market sentiment can rapidly turn capital inflows into capital flight (Stiglitz et al., 2006: 170-1). In other words, "private agents alternate between risk appetite (or, rather, underestimation of risks) and flight to quality (risk aversion) ... generating an alternation of contagion of optimism and of pessimism” (Ocampo, 2013: 6). Developing countries face higher volatility of capitals, so that they are especially vulnerable to these swings. In this context, they usually face exchange rate appreciation during the optimism phase, which is followed by sharp depreciation when risk aversion rises (Akyüz, 2011: 24).

In addition, developing countries seem to have less control on capital flow trends. Fernandez-Arias (1996: 35-6) shows that during the 1990s, capital flows to developing countries were more influenced by conditions in developed countries (push factors) -

\footnotetext{
${ }^{31} \mathrm{~A}$ trade shock is commonly followed by a financial shock. If a country is a commodity exporter and its terms of trade fall, this negative shock will cause pessimism and irradiate to the financial sector. However, not all financial shocks are due to terms of trade shocks. Moreover, according to Ocampo (2013), financial shocks have been since the mid-1970s the dominant factor when it comes to shocks affecting developing countries (Ocampo, 2013: 5).
} 
namely low international interest rates - than by domestic factors (pull factors). ${ }^{32}$ Although there were some changes in the nature of capital flows to developing countries in the 2000s, push factors were again key in capital surges to these countries (Akyüz, 2011: 8; 13; 18). ${ }^{33}$ In the specific case of Latin American economies, Medeiros (2008) shows that low interest rates in the leading economy of the world (Britain and then the United States) has always been one of the main triggers of financial booms, at least since the late 19th century.

Due to their potentially deleterious effects, many economists have long argued for capital controls as a means of reducing exposure to capital flows. According to Epstein et al. (2006: 302), "capital management techniques can promote financial stability through their ability to reduce currency flight, fragility and contagion risks, thereby reducing the potential for financial crisis and economic and social devastation”. ${ }^{34}$

The 1990s were, however, a period of enthusiasm for capital market liberalization (CML). ${ }^{35}$ The International Monetary Fund became a fierce proponent of CML. Stanley Fischer - then chief economist of the IMF - argued that "the potential benefits of

\footnotetext{
${ }^{32}$ Fernandez-Arias (1996: 36) believed, however, that a soft landing was feasible, and that large capital outflows were unlikely unless the changes in external conditions were followed by a worsening in domestic conditions. IMF (2012) sustains that "push factors seem to influence whether inflow surges occur and the riskiness of flows, while pull factors determine the direction and magnitude of such surges" (Ghosh et al., 2012 apud IMF, 2012: 16).

${ }^{33}$ Akyüz (2011) identifies two booms in capital flows to developing countries in the 2000s. The first started at the beginning of the 2000s and ended in 2008 with the international crisis. The second started shortly afterwards in 2009 and was still ongoing as he wrote. In both cases, the trigger of the boom was "low interest rates and rapid expansion of liquidity in advanced economies" (Akyüz, 2011: 8; 13). When it comes to changes in the nature of capital flows, Akyüz (2011) stresses - among other things - the increased size of capital flows, the growing importance of domestic-currency instruments in the composition of inflows, and the increase in capital flows among developing countries (Akyüz, 2011: 18) .

${ }^{34}$ According to Epstein et al. (2006), capital management techniques include both direct controls on international capital flows and prudential regulations of domestic financial institutions (Epstein et al. , 2006: 301).

35 Although the 1990s were a period of growing enthusiasm with CML, there was a series of capital controls 'experiments during this decade, including Chile, Colombia, Malaysia, Taiwan and Singapore. For a broad discussion of these experiments, see Epstein et.al. (2006).
} 
liberalizing the capital account outweigh the costs” (Fischer, 1998: 3). To reduce their exposure to capital swings, developing economies should "pursue sound macroeconomic policies, strengthen their domestic financial systems, phase capital-account liberalization appropriately, and provide information to the markets” (Fischer, 1998: 4). In the 2000s, much of this enthusiasm eroded - especially in the aftermath of the 2007-8 financial crisis (Akyüz, 2011: 37). In recent times, even the IMF has conceded that capital controls - which they call capital flow management measures (CFMs) - could prove helpful under some circumstances in country-specific cases(IMF, 2012: 8; 18). ${ }^{36}$

Thus, there is now a growing consensus on the potential benefits of capital controls. There remains the question of how to control capital movements. In practice, there are various ways of controlling capital flows. For instance, capital controls can be static or dynamic. The former relates to forms of controls that are kept unaltered whatever the circumstances, whereas the latter refers to controls that can be activated or adapted depending on the circumstances (Epstein et al., 2005: 301). Second, there are price-based regulations that impose costs on capital flows - based for instance on taxes on capital flows and/or reserve requirements - and quantity-based regulations, namely administrative restrictions or prohibitions on specific types of flows. Finally, controls can

\footnotetext{
${ }^{36}$ In the case of capital inflows, the IMF argued that CFMs can be useful in some circumstances, as when the possibility of adjusting macroeconomic policies is limited due to an overheated economy and an overvalued exchange rate. Furthermore, they argue that these controls should be temporary and nondiscriminatory (IMF, 2012: 18; 20). When it comes to capital outflows, the Fund maintains that temporary CFMs can be helpful in the context of a crisis or when a crisis is iminent. However, they argue that CFMs on outflows cannot substitute for the adjustment of macroeconomic policies (IMF, 2012: 25-6). Specifically, they argue that "outflow capital flow management measures appear more likely to be effective if they accompany sound macroeconomic policies” (IMF, 2012: 28). In sum, although the IMF recognized the possible benefits of capital controls, they kept their emphasis on sound - namely orthodox - macroeconomic policies as the main variable when it comes to preventing the risks associated with capital flows (IMF, 2012: $1-2)$.
} 
be imposed for inflows and/or outflows. Inflow controls are based on the idea that controlling the inflow will prevent bubbles and thus prevent a future outflow crisis, whereas outflow controls are usually intended to minimize the damage when capital flies to quality by reducing the amount of capital that can exit and the potential exchange rate overshooting (Stiglitz et al. 2006: 197-207).

In the 1990s, Chile and Colombia adopted price-based inflow regulations: among other things, both countries adopted non-interest-bearing reserve requirements and Chile also imposed a one-year residence requirement for foreign direct investments and portfolio investments. Following the Asian Crisis, Malaysia first adopted outflow quantity-based regulation in 1998, but then switched to outflow price-based regulation (Epstein et al., 2006: 326). More recent measures after the 2007-8 crisis include "taxes on fixed income and portfolio equity flows (Brazil), on foreigners' government bond purchases and banks' foreign exchange borrowing (Korea), or on interest income and capital gains earned by foreigners (Thailand and Korea)" (Akyüz, 2011: 37). ${ }^{37}$ There are also indirect forms of controlling capital via prudential regulations, such as restricting banks "short-term foreign borrowing or regulating the exposure to foreign exchange of firms, especially those operating in non-tradable sectors (Stiglitz et al., 2006: 216-7). ${ }^{38}$

There is thus a range of different capital controls capable of reducing the variance of exchange rate shocks. Hence, “capital controls should target the specific vulnerabilities confronted by different economies” (Chang \& Grabel, 2006: 114). In other words, there

\footnotetext{
${ }^{37}$ Akyüz (2011) discusses how developing countries coped with the surge of capital that followed the international crisis. He argues that the measures described above were insufficient to prevent the huge inflows that took place at that time (Akyüz, 2011: 36-7).

${ }^{38}$ For a list of different forms of capital controls and prudential regulation and the possible costs of implementing them, see Stiglitz et al. (2006).
} 
is no one size fits all policy, and the best mix of controls depends on the country's characteristics and circumstances (Epstein et al., 2006: 326). Moreover, this does not rule out alternative measures that can be adopted jointly with capital controls. ${ }^{39}$

In general, it is possible to identify four possible targets that usually guide policymakers when choosing the instruments to control capital movements in order to reduce the risks of capital flight: 1) prevent the over appreciation of the exchange rate during booms; 2) reduce the inflow of short-term volatile capital; 3) prevent banks and nonbanking firms from borrowing excessively in foreign currency during the risk appetite phase; ${ }^{40}$ and 4) disincentivize the exit of capital. Policy-makers can focus on one specific target or a combination of targets. The first two targets aim to control the volume of inflows and the composition of inflows, respectively. The third target clearly demands prudential regulations. Finally, the fourth requires outflow controls of some kind quantity based or price based - since its purpose is to prevent capital exit. As a result, the specific controls that a country adopts depend on which target policy-makers choose to focus on, and how they think this target is best achieved. As previously noted, the best alternatives vary from country to country. ${ }^{41}$

Two final points are worth emphasizing. First, the control of inflows may be unnecessary. If capital flows are led by push factors there will be a flight to quality in developing countries whenever there are rising interest rates in the United States

\footnotetext{
39 The accumulation of foreign reserves is an example of an alternative measure.

${ }^{40}$ As previously noted, Charles and Marie (2016) show that a country's external indebtedness is an important determinant of its vulnerability to the emergence of hyperinflation.

${ }^{41}$ Akyüz (2011) identifies three areas wherein instability and crises can emerge due to capital surges: 1) "unstainable exchange rates and current account deficits"; 2) "extensive dollarization of liabilities and currency and maturity mismatches in balance sheets"; 3) "credit and asset bubbles", when "Banks borrow abroad to fund domestic lending” (Akyüz, 2011: 22). The targets proposed above deal with all these issues.
} 
following a risk appetite phase, no matter the level of exchange rate appreciation in the developing country during the risk appetite phase. In other words, capital flight and exchange rate depreciation will happen anyway. Second, outflow controls should concentrate on price-based regulations instead of quantity-based regulations. The latter may lead to black market operations and other sorts of deviations. The former seems to be more efficient because outflows are not prohibited. Price-based outflow regulations are based on taxes on outflows that introduce sand in the gears, thus tending to discourage these flows. ${ }^{42}$

In sum, while there are multiple possible strategies among which countries can choose according to their needs, it seems that developing countries aiming to reduce their exposure to exchange rate shocks would be best advised to adopt price- rather than quantity-based regulations on capital outflows and avoid controls on inflows.

\section{2.ii - Terms of Trade Shocks}

Terms of trade shocks relate to problems that have more structural roots. If a country's productive structure is dominated by primary goods, it will not likely escape the negative terms of trade effects when primary goods prices fall in international commodity markets. Reducing exposure to this type of external shock thus requires structural solutions. This was precisely the focus of the LASS in the 1950s and 1960s.

The LASS argued that Latin American countries suffered a structural bias towards external disequilibrium due to their narrow productive structure and exports basket. For instance, Raul Prebisch - the school's founding father - argued explicitly that there was a

\footnotetext{
${ }^{42}$ We thank Franklin Serrano for calling our attention to these points.
} 
tendency towards deterioration of the region's terms of trade. ${ }^{43}$ Accordingly, the LASS advocated induced industrialization (Bastos, 2002: 81).

The structuralist manifesto draws attention to the potential importance of industrial policy in the way later suggested by Chang (2003:112): “as a policy aimed at particular industries (and firms as their components) to achieve the outcomes that are perceived by the state to be efficient to the economy as a whole”. In the context of the model developed in section 3, reducing external vulnerability fits perfectly with Chang's notion of an outcome that is efficient for the economy as a whole.

This having been said, there have been various transformations in the industrial sector in recent decades that policy-makers in developing countries must confront when formulating industrial policies. First, firms now concentrate on their core business and have expanded the outsourcing of peripheral operations. Thanks to the boom in information technology, this process has led to the emergence of global value chains (GVCs), meaning that in many cases parts of final goods are produced all around the globe. As a result, there has been substantial growth in international trade in intermediate goods. Furthermore, exports now have higher import content, and imports have higher export content (Milberg et al., 2014: 152; 165-66; 173). Second, there has been a process of industrial concentration in almost every sector and sub-sector of the economy, due to multinationalization. Hence,

\footnotetext{
${ }^{43}$ Heintz (2006) synthesizes the arguments of Raul Prebisch - and also Hans Singer - in the following way: "First, the institutions of the industrial North have sufficient market power to cause prices and wages to be stickier than is the case in the developing world, where greater flexibility prevails. Second, the income elasticity of demand for manufactured goods is higher than that of primary goods. Therefore, demand for manufactured goods responds vigorously to productivity improvements that raise incomes. However, the demand for primary goods responds weakly (or possibly even negatively) to technological innovations. Therefore, during periods of productivity-led growth, prices of manufactured goods rise relative to prices of primary products. Since primary commodities are price inelastic, the income terms of trade - that is, receipts from exports relative to imports - fall, leading to a widening gap between industrialized and developing countries" (Heintz, 2006: 510).
} 
"the number of companies shrank and the leading companies in each sector usually have superior technologies and powerful brands” (Nolan, 2012: 17).

Competing in a world of GVCs and large multinationals is challenging for developing countries. Milberg et al (2014) suggest that the traditional strategies of import substitution or export promotion have become somewhat obsolete in this new context. As "exports and imports are entangled", the result is that "the policies that affect exports and imports are no longer going to be as effective as they should be in a world absent of GVCs" (Milberg et al., 2014: 173). Accordingly, the focus of contemporary industrial policies must be on upgrading within GVC's - i.e., promoting “the possibility for (developing country) producers to move up the value chain, either by shifting to more rewarding functional positions or by making products that have more value added invested in them and that can provide better returns to producers” (Gibbon and Ponte, 2005, pp. 87-88 apud Milberg et al., 20the 14: 159).

At present, developed countries dominate the niches wherein most of the value added is appropriated, namely R\&D, design, branding and sales (OECD, 2013: 194 apud Medeiros \& Trebat, 2016: 10). What can developing countries do to change the game? There are multiple strategies that they can pursue. ${ }^{44}$ Medeiros and Trebat (2016) suggest that at the core of any industrial policy aiming at upgrading in GVC's there must be one fundamental element: building and improving technological capabilities. Moving to more rewarding functional positions and/or making goods with more value added invested in them both require technological capabilities. Therefore, among other things, contemporary industrial policies call for public investment in infrastructure, technological and

\footnotetext{
${ }^{44}$ Milberg et al (2014) provide an extensive list of the challenges and possible strategies for developing countries regarding upgrading in GVC's.
} 
educational policies aimed at building and improving public laboratories and universities, and improving the skills of the labor force (Medeiros \& Trebat, 2016: 3; 19-21).

In sum, "the case for industrial policy has not diminished but rather has changed as a result of the globalization of production” (Milberg et al., 2014: 173). The focus has shifted from building industrial structures or promoting exports to the development of technological capabilities. Our analysis suggests that beyond its primary purpose, this reoriented industrial policy can play a role in reducing the structural vulnerability of developing economies to the permanent inflationary consequences of transitory external shocks.

\section{3 - Strategies for reducing conflicting claims}

In the event that a country cannot reduce the variance of its nominal exchange rate, there remains the possibility of reducing the exposure to a wage-price inflationary spiral following nominal exchange shocks. This requires focusing attention on the policies and institutions that affect labor markets.

One way to manage conflicting claims due to exchange rate shocks involves pursuing a social democratic model. ${ }^{45}$ This model is inspired by the experience of Western European countries after the Second World War, a period known as the Golden Age (1948-73). ${ }^{46}$ During this period, the widespread diffusion of social safety nets, public

\footnotetext{
${ }^{45}$ According to Bhaduri (2011), social democracy was born in the second half of the 19th century as a result of universal suffrage in Western Europe. During this period, the growing political rights of the labor class posed a challenge to the revolutionary socialists, paving the way for reformist socialism. Social democracy peaked after World War II with the combination of the welfare state and full employment policies (Bhaduri, 2011: 41-51).

${ }^{46}$ As there were differences among countries, what we call a social democratic model is a simplification based on some general aspects of these countries' experiences For instance, Esping-Andersen (1990) reserves the term social democratic for a specific type of welfare state that predominated in Scandinavian countries (Esping-Andersen, 1990: 26-29). Schmidt (2011) refers generally to the Western European welfare states of
} 
health systems, education systems, and labor market regulations, together with the commitment of macroeconomic policy to achieving and maintaining full employment, created a "social pact" between classes (Bhaduri, 2011). ${ }^{47}$ At the core of the social democratic model is the "(at least partial) reconciliation of the distributional goals of workers and firms by means of a conventional wage share that [is], broadly speaking, mutually acceptable to both workers and firms” (Setterfield, 2006: 52). Hence, in the social democratic model gains and losses are divided between firms and workers.

In terms of the model developed in section 3, the social democratic solution means that an external shock is unlikely to lead to a real wage that falls below worker's minimum tolerable level $\left(w_{w}-w<c\right)$. It is true that there will be some wage and price inflation following an external shock. However, these are short run readjustments. As previously noted, losses are divided between firms and workers, so that a transition from an equilibrium inflation regime to a strato-inflation regime is unlikely. Social partnership institutions contain the inflationary pressures stemming from the shock, thus preventing a long-lasting retaliatory dynamic.

The social democratic differs from the neoliberal model. This model rose to prominence in the late 1970s and is associated with the governments of Ronald Reagan in the United States and Margaret Thatcher in the United Kingdom in the 1980s, though it was implemented worldwide during the 1980s and 1990s. In general, neoliberal adherents "consider collective bargaining and the welfare state as institutions encouraging rent-

the period 1950-1980 as Keynesian welfare states, but also recognizes that there were differences from one country to another (Schmidt, 2011: 475).

47 According to Schmidt (2011), "the Keynesian welfare state rested on a bloc that was formed around a compromise between organized labor, mostly semiskilled or skilled blue-collar workers, and large industrial corporations. The former got the right to negotiate wage increases, the latter got industrial peace and, thanks to increased wage bills, a stable customer base” (Schmidt, 2011: 481). 
seeking behavior and as deterrents to entrepreneurial activity. To restore the latter, and thus unleash growth, unions and the welfare state had to be rolled back" (Schmidt, 2011: 479).

The neoliberal model prevents an acute conflicting-claims dynamic in the labor market by weakening worker's bargaining power. ${ }^{48}$ Such a strategy is developed through institutional reforms that lead to labor market deregulation and economic openness. Usually these reforms rule out worker's rights, facilitate dismissals, encourage contracting out and downsizing and discourage the formation of trade unions. As a result, there is an increase in employment and/or income insecurity among workers (Setterfield, 2006: 49). This insecurity works as a mechanism of control: even absent high unemployment, workers are put under pressure by the risk of job loss. Hence, trade unions lose part of their bargaining power. In other words, labor market deregulation disciplines trade unions.

In terms of the analysis developed here, it is possible to say that after the government implements a neoliberal model worker's actual bargaining power $(\mu)$ is reduced. Therefore, there is a reduction in the slope of the wage inflation curve and a reduction in the equilibrium rate of inflation. It is also reasonable to suppose that the minimum real wages that workers target will also fall. Both developments reduce the likelihood of an inflationary spiral following an external shock.

Moreover, there is also a reduction in workers’ potential bargaining power $\left(\mu_{\max }\right)$. In this way, if workers do begin to bargain harder after a real wage fall due to an external shock, their ability to participate in the resulting retaliatory dynamic will be limited. In

\footnotetext{
${ }^{48}$ Schmidt (2011: 479) argues that neoliberalism's goal "is not to reduce state capacities but to turn them against unions and social spending”.
} 
other words, the fall in workers maximum bargaining power reduces the chances of the economy entering a strato-inflation regime and also dampens the disequilibrium dynamics that can unfold after the economy enters a strato-inflation regime. In short, the neoliberal model is a distributionally regressive way of preventing a wage-price spiral following a shock. ${ }^{49}$

The preceding discussion suggests that there exists a choice between social democratic and neoliberal models. However, there are some caveats when it comes to implementing a social democratic model in contemporary developing economies.

First, there is the issue of the resilience of the social democratic model in the face of rising inflation following exchange rate shocks. Some authors argue that social democratic institutions during the Golden Age were disrupted by the rise in inflation rates - associated with rising real wages and declining productivity growth - at the end of the 1960s and early 1970s (Glyn, 1995: 115-6). In other words, the collective bargaining of the Golden Age accommodated conflicting claims before inflation accelerated in the late 1960s and early 1970s, but failed thereafter. On one hand, workers fought for higher wages to compensate for accelerating inflation, leading to labor-capital conflicts and also rivalries within the labor movement associated (for instance) with conflicts between organized and unorganized workers, and between public- and private-sector workers

\footnotetext{
${ }^{49}$ In developing countries, exchange rate pass-through to inflation seems to be getting smaller in the recent decades. This raises the question of why this has been the case. One possible explanation is tight monetary policy in response to external shocks. As Abeles and Panigo (2015) observe in the context of an international commodity shock, conventional wisdom recommends to prevent second-round inflationary effects following such a context shock, meaning adopting contractionary monetary policy to cool off the economic activity and thus keep wage demands under control (Abeles \& Panigo, 2015: 519; 522). Another possible explanation is the very neoliberal labour market reforms that have been spread in the developing world from the late 1980s on, which have reduced the capacity of workers to resist real wage losses due to inflation rises stemming from inflationary shocks. In both cases the reduction of the exchange rate passthrough to inflation is ultimately explained by a reduced space for wage demands.
} 
(Schmidt, 2011: 481-3). On the other hand, firms were also discontent because the low levels of unemployment led to rising real wages and declining profits. Thus, rising inflation in the 1970s - combined with stagnant growth rates - exacerbated conflict, undermined the legitimacy of the welfare state, and paved the way for the ascent of neoliberalism (Schmidt, 2011: 483). ${ }^{50}$ This thinking is disputed, however, by Crouch (1985). He shows that inflation in the 1970s - following the first oil shock - was in general lower on average in countries with centrally coordinated union movements (neocorporatist systems, such as Austria, the Netherlands, and the former West Germany) than in countries without significant centralized coordination (liberal systems, such as the United Kingdom and the United States) (Crouch, 1985: 113-124). The rivalries and conflicts that lead to an inflation upsurge following a cost shock tend to occur in a context in which unions are fragmented and uncoordinated, so that "where labor's organizations are centrally coordinated and have achieved a secure level of acceptance within the polity their disruptive activity will be considerably reduced” (Crouch, 1985: 114). Hence, a more centralized union movement offers more protection against acute conflicting claims and high inflation in the face of cost shocks.

In any case, the context today is more complex for social democracy than it was in the 1970s or earlier. Globalization and the emergence of GVCs have reduced the potential bargaining power of workers by rendering them subject to (for instance)

\footnotetext{
${ }^{50}$ At the core of the problem is Kalecki's (1943) observation that capitalists dislike full employment because it empowers workers, as a result of which firms demand deflationary macro policies that produce unemployment and reduce workers' bargaining power. Schmidt (2011) argues along these lines when he states that in the late 1960s and early 1970s, workers "were in a position to defend their real wages in case of any external inflationary shock, such as the inflationary way of paying for the Vietnam War in the late 1960s or rising oil prices in the 1970s", but "in an attempt to maintain their profit rates, employers would retaliate through price increases and thus produce the accelerated inflation they needed as a pretext to turn against the Keynesian welfare state” (Schmidt, 2011: 479). Yet, as previously noted, Schmidt also recognizes the role played by labor rivalry in "eroding the Welfare State bloc" (Schmidt, 2011: 484-5).
} 
credible threats of plant closure. This is true in the developed world, ${ }^{51}$ but developing countries are especially vulnerable to plant relocation since they concentrate on the low value added links in GVCs, wherein competition is fierce and based on low labor costs.

Finally, there is the political issue of how to build social democratic institutions in developing countries. Institutional change frequently involves conflict because it creates winners and losers. The emergence of social democratic institutions in developing countries is complicated by the fact that such institutions have been rare in the developing world, while developing countries typically house powerful elites that may not be incined towards concessions. In fact, even in developed countries that have a tradition of welfarism, the recent trend has been towards a retreat from (rather than advance towards) social democratic institutions. In sum, building social democratic institutions in developing countries may be an appropriate target, but will not be easy to accomplish.

\section{Conclusions}

In this paper, we have developed a model of inflation in an open economy in which a (seemingly) temporary increase in inflation arising from a transitory exchange depreciation has permanent inflationary consequences. This result arises from our treatment of the dynamics of inflation in a conflicting claims framework, which we characterize as discontinuous, with the result that discretely different inflation regimes (equilibrium inflation and strato-inflation) give rise to threshold effects as a result of which transitory foreign exchange shocks may (but need not) have permanent inflationary consequences. We identify sources of structural vulnerability to such

\footnotetext{
${ }^{51}$ For an account of the problem in the United States in the 1990s, see Bronfrenbrenner (1996).
} 
outcomes, and the means of addressing these structural vulnerabilities are outlined and assessed.

Ultimately, our analysis can be thought of as establishing a structuralist inflation targeting agenda that, based on a proper conception of the (discontinuous) dynamics of inflation, involves “getting inflation targeting right”. In mainstream analysis, inflation targeting involves picking an (ultimately arbitrary) inflation target, and neglecting any and all other macroeconomic objectives in the pursuit of its achievement. ${ }^{52}$ In their eagerness to promote the importance of other macroeconomic objectives, critics of this mainstream approach, meanwhile, can sometimes appear to have little or nothing to say about inflation (see, for example, Setterfield, 2006). A structuralist inflation targeting agenda centres on the notion that any approach to inflation targeting needs to begin with a proper understanding of inflation dynamics. As suggested in this paper, the latter are fundamentally non-linear: there are marked differences between equilibrium inflation regimes (which exist within a band defined primarily by real wage bargaining dynamics) and what lies beyond (strato- and ultimately hyper-inflation regimes). In this sense, we can immediately see that the oft-repeated aphorism, that "a small inflation is rather like a small pregnancy,” is simply not true: qualitative differences exist between inflation rates that lie within different bands. What is required for successful inflation control is not that the rate of inflation be kept at or close to some arbitrary value, but rather that it be kept within the band of rates consistent with an equilibrium regime. Moreover, it needs to be recognized that economies can redress the structural vulnerabilities that, unattended,

\footnotetext{
${ }^{52}$ See, for example, Mishkin (2002, p.361). See also McKnight et al (2016) for evidence that the majority of the "big five" Latin American inflation targeters (Brazil, Chile, Colombia, Mexico and Peru) behave in accordance with this mainstream approach.
} 
increase the chances that even a temporary shock can cause an economy to transition out of an equilibrium regime. In other words, policy can reduce the susceptibility of an economy to worst-case inflation outcomes (associated with the onset of strato-inflation dynamics), but without sacrificing other macroeconomic performance objectives at the altar of inflation. Together, these propositions are the essence of a structuralist inflation targeting agenda.

\section{APPENDIX A: Derivatives involved in the construction of Figure 3.}

Given that:

$$
p^{*}=\frac{\mu_{1} \phi_{1}\left[\left(\omega_{w 0}-\omega_{f 0}\right)+\left(\mu_{2}+\phi_{2}\right) e_{R}\right]}{\mu_{1}+\phi_{1}}
$$

(as in equation [14]), define:

$$
\Gamma=\frac{\mu_{1} \phi_{1}\left(\omega_{w 0}-\omega_{f 0}\right)}{\mu_{1}+\phi_{1}}
$$

and:

$$
\Upsilon=\frac{\mu_{1} \phi_{1}\left(\mu_{2}+\phi_{2}\right)}{\mu_{1}+\phi_{1}}
$$

It follows from [A1] that:

$$
\frac{d \Gamma}{d \mu_{1}}=\frac{\phi_{1}^{2}\left(\omega_{w 0}-\omega_{f 0}\right)}{\left(\mu_{1}+\phi_{1}\right)^{2}}>0
$$

and:

$$
\frac{d \Gamma}{d \phi_{1}}=\frac{\mu_{1}^{2}\left(\omega_{w 0}-\omega_{f 0}\right)}{\left(\mu_{1}+\phi_{1}\right)^{2}}>0
$$

so that: 


$$
d \Gamma=\frac{\partial \Gamma}{\partial \mu_{1}} d \mu_{1}+\frac{\partial \Gamma}{\partial \varphi_{1}} d \varphi_{1}>0
$$

for $d \mu_{1}, d \varphi_{1}>0$. At the same time, it follows from [A2] that:

$$
\frac{d \Upsilon}{d \mu_{1}}=\frac{\phi_{1}^{2}\left(\mu_{2}+\phi_{2}\right)}{\left(\mu_{1}+\phi_{1}\right)^{2}}>0
$$

and:

$$
\frac{d \Upsilon}{d \varphi_{1}}=\frac{\mu_{1}^{2}\left(\mu_{2}+\phi_{2}\right)}{\left(\mu_{1}+\phi_{1}\right)^{2}}>0
$$

so that:

$$
d \Upsilon=\frac{\partial \Upsilon}{\partial \mu_{1}} d \mu_{1}+\frac{\partial \Upsilon}{\partial \varphi_{1}} d \varphi_{1}>0
$$

for $d \mu_{1}, d \varphi_{1}>0$.

Meanwhile, given that:

$$
e^{*}=\frac{\mu_{1} \phi_{1}\left(\omega_{w 0}-\omega_{f 0}\right)-\left(\mu_{1}+\phi_{1}\right) \bar{p}_{f}}{\mu_{1}+\phi_{1}}+\frac{\mu_{1} \phi_{1}\left(\mu_{2}+\phi_{2}\right)}{\mu_{1}+\phi_{1}} e_{R}
$$

(as in equation [15]), define:

$$
\Omega=\frac{\mu_{1} \phi_{1}\left(\omega_{w 0}-\omega_{f 0}\right)-\left(\mu_{1}+\phi_{1}\right) \bar{p}_{f}}{\mu_{1}+\phi_{1}}
$$

and:

$$
\Psi=\frac{\mu_{1} \phi_{1}\left(\mu_{2}+\phi_{2}\right)}{\mu_{1}+\phi_{1}}
$$

It follows from [A3] that:

$$
\frac{d \Omega}{d \mu_{1}}=\frac{\phi_{1}^{2}\left(\omega_{w 0}-\omega_{f 0}\right)+\left(1-\phi_{1}\right)\left(\mu_{1}+\phi_{1}\right) \bar{p}_{f}}{\left(\mu_{1}+\phi_{1}\right)^{2}}>0 \text { if } \varphi_{1}<1
$$

and: 


$$
\frac{d \Omega}{d \varphi_{1}}=\frac{\mu_{1}^{2}\left(\omega_{w 0}-\omega_{f 0}\right)+\left(1-\mu_{1}\right)\left(\mu_{1}+\phi_{1}\right) \bar{p}_{f}}{\left(\mu_{1}+\phi_{1}\right)^{2}}>0 \text { if } \mu_{1}<1
$$

so that:

$$
d \Omega=\frac{\partial \Omega}{\partial \mu_{1}} d \mu_{1}+\frac{\partial \Omega}{\partial \varphi_{1}} d \varphi_{1}>0
$$

for $d \mu_{1}, d \varphi_{1}>0$. At the same time, it follows from [A4] that:

$$
\frac{d \Psi}{d \mu_{1}}=\frac{\phi_{1}\left(\mu_{2}+\phi_{2}\right)}{\left(\mu_{1}+\phi_{1}\right)^{2}}>0
$$

and:

$$
\frac{d \Psi}{d \phi_{1}}=\frac{\mu_{1}\left(\mu_{2}+\phi_{2}\right)}{\left(\mu_{1}+\phi_{1}\right)^{2}}>0
$$

so that:

$$
d \Psi=\frac{\partial \Psi}{\partial \mu_{1}} d \mu_{1}+\frac{\partial \Psi}{\partial \varphi_{1}} d \varphi_{1}>0
$$

for $d \mu_{1}, d \varphi_{1}>0$. 


\section{References}

Abeles, M. and Panigo, D. (2015). “Dealing with cost-push inflation in Latin America: multi-causality in a context of increased openness and commodity price volatility”, Review of Keynesian Economics, vol. 3, no4, pp.517-535.

Akyüz, Y. (2011) Capital Flows To Developing Countries In A Historical Perspective: Will The Current Boom End With A Bust? South Centre, Research Papers, 37.

Bastian, Eduardo F.; Bastos, Carlos; Bielschowsky, Ricardo and Júlia Braga (2016) “Some stylized facts on external shocks and inflation upsurge in Brazil, 1951-1985”, Texto para Discussão 028-2016 (Discussion Paper No. 028-2016), Instituto de Economia Universidade Federal do Rio de Janeiro (IE-UFRJ).

Bastian, Eduardo F. and Mark Setterfield (2015) A simple analytical model of the adverse real effects of inflation. Journal of Post Keynesian Economics, v. 38, n. 4, pp. 637-665.

Bastos, C. (2002) "Price Stabilization in Brazil: A Critical Review and a Classical Interpretation for an Indexed Nominal Interest Rate Economy.” Unpublished Ph.D. dissertation, New School University.

Bhaduri, A (2011) “La política económica de la socialdemocracia”. In: Repensar la Economía Política. Buenos Aires: Manantial.

Bhaduri, A. and S. Marglin (1990) "Unemployment and the real wage: the economic basis for contesting political ideologies,” Cambridge Journal of Economics, 14, pp. 37593.

Blecker, R.A. (1989) "International competition, income distribution and economic growth,” Cambridge Journal of Economics, 13, pp. 395-412.

Blecker, R.A. (2011) “Open economy models of distribution and growth,” in E. Hein and E. Stockhammer (eds) A Modern Guide to Keynesian Macroeconomics and Economic Policies, Cheltenham, UK: Edward Elgar, pp. 215-39.

Bresciani-Turroni, Constantino (1937) The Economics of Inflation: A Study of Currency Depreciation in Post War Germany, London, Routledge.

Bronfrenbrenner, K. (1997) "We'll Close! Plant Closings, Plant-Closing Threats, Union Organizing and NAFTA”. Special Report - Cornell University ILR School. http://digitalcommons.ilr.cornell.edu/cgi/viewcontent.cgi?article=1018\&context=cbpubs

Câmara, Alcino and Matias Vernengo (2001)“The German Balance of Payment School and the Latin American Neo-Structuralists”, in Rochon, Louis Philippe, Matias Vernengo (ed.), Credit, Interest Rates and the Open Economy, Cheltenham, Edward Elgar, pp. 143159. 
Charles, Sebastien and Jonathan Marie (2016) "Hyperinflation in a small open economy with a fixed exchange rate: A post Keynesian view”, Journal of Post Keynesian Economics, vol. 39, no. 3, pp. 361-386.

Chang, H.J. (2003) “The Political Economy of Industrial Policy”. In: Globalisation, Economic Development and the Role of the State. Londres: Zed Books.

Chang, H. J. and I. Grabel (2006). Reclaiming Development - an alternative economic policy manual. London: Zed Books.

Chick, V. and M. Caserta (1997) "Provisional Equilibrium and Macroeconomic Theory.” In P. Arestis, G. Palma, and M. Sawyer (eds.), Markets, Unemployment and Economic Policy: Essays in Honour of Geoff Harcourt, vol. 2. London: Routledge, 1997, pp 223-237.

Crouch, C. (1985) "Conditions for trade union wage restraint," in Lindberg and Maier (eds) The Politics of Inflation and Economic Stagnation, Brookings Institution.

Epstein, G. A., Ilene Grabel and Kwame Sundaram Jomo (2005), “Capital ManagementTechniques in Developing Countries”, in Gerald A. Epstein (ed.) Capital Flight and Capital Controls in Developing Countries. Cheltenham: Edward Elgar.

Esping-Andersen, G. (1990) The Three Worlds of Welfare Capitalism. Princeton: Princeton University Press.

Fischer, S. (1998) “Capital-Account Liberalization and the Role of the IMF”. Essays in International Finance, n. 207, International Finance Section, Department of Economics, Princeton University, pp 1-10.

Glyn, A. (1995) “Social Democracy and Full Employment”. Nordic Journal of Political Economy, vol. 22, pp. 109-126.

Heintz, J. (2006) "Low-wage manufacturing and global commodity chains: a model in the unequal exchange tradition”. Cambridge Journal of Economics, 30, pp.

Helfferich, K. (1927) Money, New York, The Adelphi Company.

IMF (2012) “The Liberalization And Management Of Capital Flows: An Institutional View”. International Monetary Fund, 14 November 2012.

Jackson, D. and Turner, H. (1972) “Inflation, Strato-inflation and Social Conflict.” In D. Jackson, H. Turner, and F. Wilkinson Do Trade Unions Cause Inflation?

Department of Applied Economics, University of Cambridge, Occasional Paper 56, Cambridge University Press. 
Kalecki, M. (1962) “A Model of Hyperinflation,” Manchester School of Economics and Social Studies, 30, 275-281.

Kalecki, M. (1971) “Costs and Prices.” In Selected Essays on the Dynamics of the Capitalist Economy. Cambridge: Cambridge University Press, 1971, pp 43-61.

Lavoie, M. (1992) Foundations of Post-Keynesian Economic Analysis, Aldershot, Edward Elgar

Lavoie, M. (2014) Post-Keynesian Economics: New Foundations, Cheltenham, UK: Edward Elgar.

Lustig, N. (1988) "Del Estructuralismo al Neoestructuralismo: la busqueda de un paradigm heterodoxo”, Colección de Estudios Cieplan, n.23, pp.35-50.

Medeiros, C. (2008) "Financial dependency and growth cycles in Latin American countries”, Journal of Post Keynesian Economics, v. 31, n. 1, pp. 79-99.

Medeiros, C. and Trebat, N. (2016). "Latin America at the crossroads: controversies on growth, income distribution and structural change.” Texto para Discussão 022-2016 (Discussion Paper 022-2016), Instituto de Economia - Universidade Federal do Rio de Janeiro (IE-UFRJ).

McKnight, S., A. Mihailov and A.P. Rang el (2016) "What do Latin American inflation targeters care about? A comparative Bayesian estimation of central bank preferences," Discussion Paper No. 129, department of Economics, University of Reading.

Milberg, W.; Jiang, X. and Gereffi, G. (2014) "Industrial policy in the era of vertically specialized industrialization”. In: Jose M. Salazar-Xirinachs, Irmgard Nubler, Richard Kozul-Wright (ed.) Transforming Economies: Making Industrial Policy Work for Growth, Jobs and Development. Geneva: International Labour Office. pp. 151-178.

Mishkin, F.S. (2002) “Inflation targeting," in B. Snowdon and H.R Vane (eds) An Encyclopedia of Macroeconomics, Cheltenham, UK, Edward Elgar, pp.361-65.

Nolan, P. (2006) Is China Buying the World? Cambridge: Polity Press.

Ocampo, J.A. (2013) "Balance of payments dominance: its implications for macroeconomic policy”, Initiative for Policy Dialogue, Working Paper series.

Pazos, F. (1969) Medidas para detener la inflación crónica en América Latina. Ciudad de Mexico: Centro de Estudios Monetarios Latinoamericanos.

Ribeiro, R.S.M., J.S.L. McCombie, and G.T. Lima (2016) "Some unpleasant currency devaluation arithmetic in a Post-Keynesian macromodel,” Department of Economics FEA/USP Working Paper No. 2016-03 
Robinson, J. (1938) “A Review of The Economics of Inflation by Bresciani-Turroni”, Economic Journal, vol. 48, 191, London, Royal Economic Society, pp. 507-513.

Rodríguez, O. (2006) O Estruturalismo Latino-Americano. Rio de Janeiro; Civilização Brasileira.

Rowthorn, R.E. (1977) “Conflict, Inflation and Money.” Cambridge Journal of Economics, 1977, 1, pp. 215-239.

Setterfield, M. (2006) Balancing the macroeconomic books on the backs of workers: a simple Analytical Political Economy model of contemporary US capitalism. International Journal of Political Economy, 35, 46-63.

Setterfield, M. (2006) Is inflation targeting compatible with Post Keynesian economics?, Journal of Post Keynesian Economics, vol. 28, issue 4, pp. 653-671.

Setterfield, M. (2009) "Path dependency, hysteresis and macrodynamics,” in P. Arestis and M. Sawyer (eds) Path Dependency and Macroeconomics (International Papers in Political Economy 2009), London, Palgrave Macmillan, 37-79.

Stiglitz, J.; Ocampo, J.A.; Spiegel, S.; French-Davis, R. and D. Nayyar (2006) Stability with Growth: Macroeconomics, Liberalization and Development (Initiative for Policy Dialogue. Oxford: Oxford University Press.

Schmidt, I. (2011)“There were alternatives: lessons from efforts to advance beyond Keynesian and neoliberal economic policies in the 1970s”, The Journal of Labor and Society, volume 14, pp. 473-498.

Schröder, E. (2015) “Offshoring, employment and aggregate demand,” New School for Social Research, mimeo.

Taylor, L. (2004), Reconstructing Macroeconomics: Structuralist Proposals and Critiques of the Mainstream, Cambridge, MA: Harvard University Press.

Vera, L. (2010) Conflict inflation: an open economy approach. Journal of Economic Studies, Vol. 37 No. 6, pp. 597-615. 
Figure 1: Equilibrium in the extended conflicting claims model

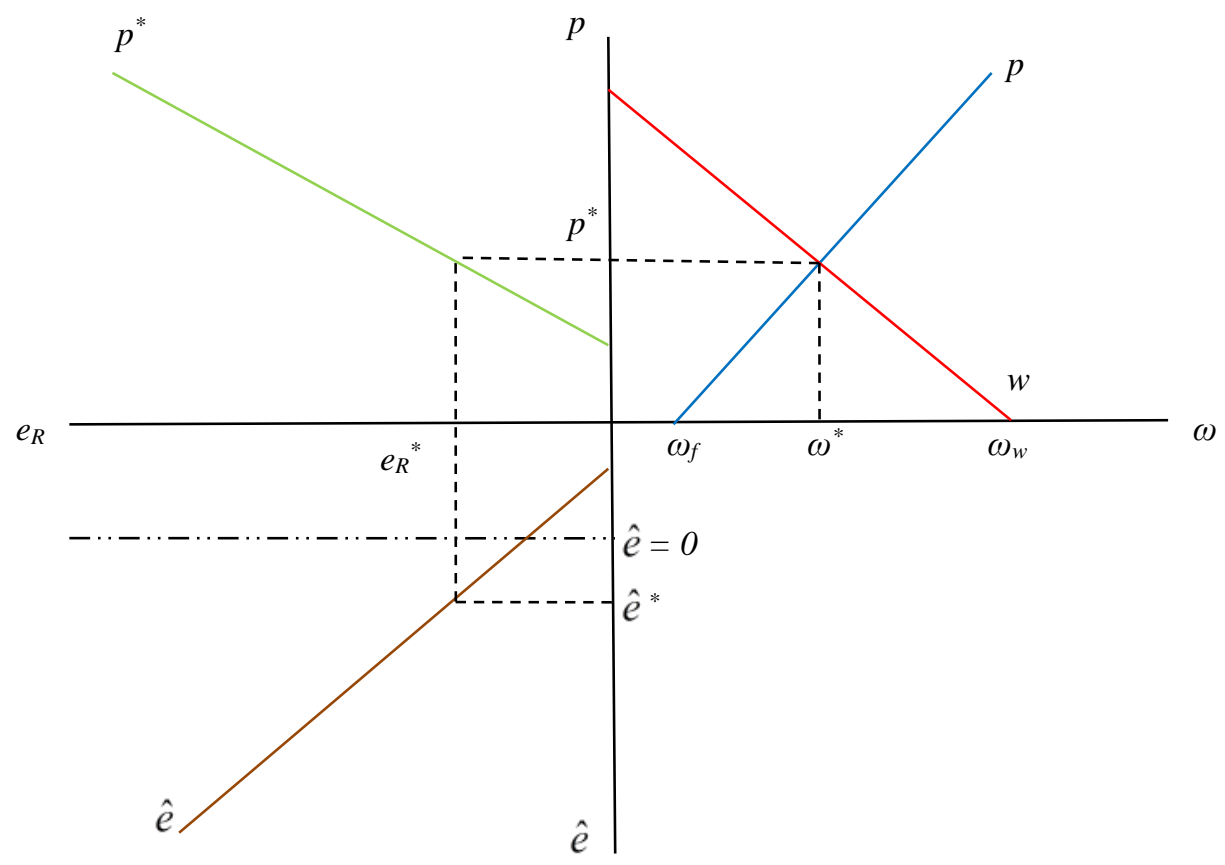


Figure 2: The effects of a nominal exchange rate shock

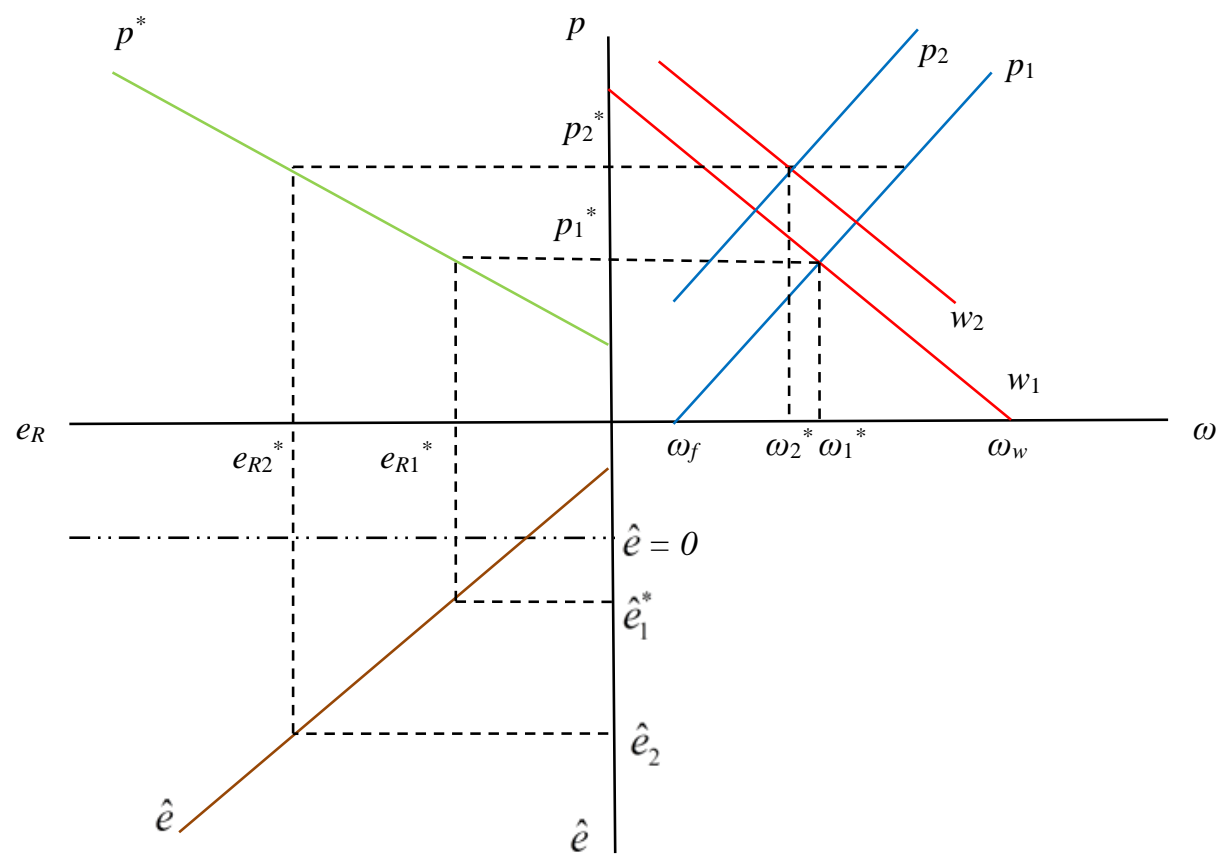


Figure 3: The long-term inflationary consequences of a transitory nominal exchange rate shock

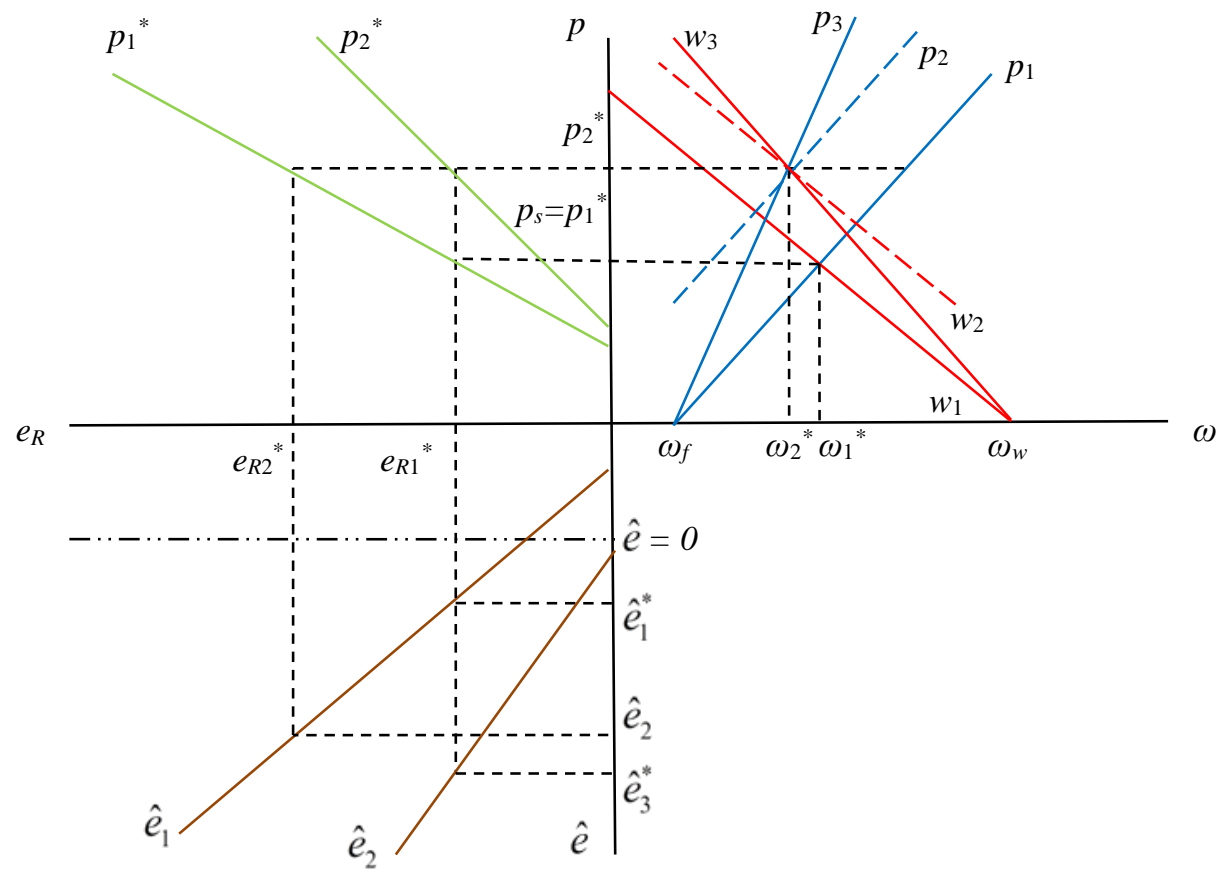

